Reprinted from the

New York University Annual Survey of American Law

Vertical LeVERAGE AND tHe SACRIFICE Principle: Why the SuPREME CourT GOT TRINKO WRONG

Nicholas Economides

Volume 61

Issue 3

2005 


\title{
VERTICAL LEVERAGE AND THE SACRIFICE PRINCIPLE: WHY THE SUPREME COURT GOT TRINKO WRONG ${ }^{\dagger}$
}

\author{
NICHOLAS ECONOMIDES*
}

\begin{abstract}
Trinko, a local telecommunications services customer of AT\&T, sued Verizon for anti-competitively raising the costs of AT\&T, Verizon's rival in the market for local telecommunications services. Pursuant to the rules of the Telecommunications Act of 1996, AT\&T was leasing parts of the local telecommunications network (unbundled network elements, "UNEs") from Verizon at "cost plus reasonable profit" prices. The Supreme Court held that Trinko's complaint failed to state a claim under $\S 2$ of the Sherman Act, and dismissed the complaint. I argue that the Court drew incorrect inferences from its Aspen Skiing decision. The Court also missed a key vertical leveraging issue in Trinko. The opening of competition mandated by the Telecommunications Act of 1996 challenged Verizon's traditional monopoly in the local telecommunications services market. By raising the cost and/or decreasing the quality of the service of rivals in the retailing services market, Verizon aimed to preserve that monopoly. As a result of these efforts, rivals suffered a disadvantage. Yet Verizon also caused retailing rivals to lease a lower number of unbundled network elements and thus incurred a revenue sacrifice. Therefore the actions of Verizon in raising the costs of retailing telecommunications services rivals are an indication of. liability according to the. "sacrifice principle" proposed in the Government's brief in Trinko, according to which a defendant is liable if its conduct "involves a sacrifice of short-term profits or goodwill that makes sense only insofar as it helps the defendant maintain or obtain monopoly power," even

$\dagger$ I thank Harry First, Eleanor Fox, Larry White, and participants at the NYU Annual Survey of American Law Antitrust Symposium for their comments and suggestions and the staff of the NYU Annual Survey of American Law for their editorial assistance.

* Stern School of Business, NYU, 44 West 4th Street, New York, NY 10012, email: neconomi@stern.nyu.edu, www: http://www.stern.nyu.edu/networks/, Tel. (212) 998-0864, Fax (212) 995-4218, and Executive Director, NET Institute, http:/ /www.NETinst.org.
\end{abstract}


though the sacrifice principle defines a stringent condition for a finding of liability.

\section{CONTENTS}

I. Introduction $\ldots \ldots \ldots \ldots \ldots \ldots \ldots \ldots \ldots \ldots \ldots \ldots \ldots \ldots \ldots, \quad 380$

II. Background on Telecommunications Market ...... 382

A. The 1981 Breakup of AT\&T ............... 382

B. What is a Vertical Price Squeeze and How Does it Lead to the Foreclosure of Downstream Rivals by an Upstream Monopolist? ................. 385

C. Foreclosure Through Raising Rivals' Costs ...... 388

D. Summary of the Telecommunications Act of

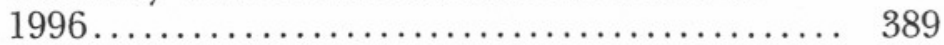

E. Implementation of the Telecommunications Act . 397

III. Summary of the Supreme Court Decision in Trinko .. 400

IV. Issues and Problems Arising from the Trinko Decision ................................. 402

V. Vertical Leverage in Trinko, Raising Rivals' Costs..... 407

A. Foreclosure Through a Vertical Price Squeeze ... 407

B. Foreclosure Through Raising Rivals' Costs ...... 409

VI. Application of the Profit "Sacrifice Principle" ....... 410

VII. Concluding Remarks ....................... 412

\section{I. \\ INTRODUCTION}

The Verizon Communications Inc. v. Law Offices of Curtis V. Trinko ${ }^{1}$ decision is a major interpretation by the Supreme Court of the conditions under which a Sherman Act section 2 monopolization violation can be sustained. ${ }^{2}$ Trinko, a purchaser of local telecommunications services from AT\&T, sued Verizon for raising the costs of and otherwise disadvantaging AT\&T through anti-competitive actions. ${ }^{3}$ AT\&T, which was Verizon's rival in the retail local telecommunications services market, was leasing parts of the local telecommunications network infrastructure, or unbundled network elements (hereinafter "UNEs"), from Verizon according to the rules of the Telecommunications Act of 1996. These rules imposed on the leases a "just and reasonable rate . . . based on the cost". that "may include a reasonable profit" and a requirement that the rate

1. 540 U.S. 398 (2004).

2. See generally id.

3. Id. at $402-05$. 
be "nondiscriminatory." 4 The Supreme Court held that Trinko's complaint failed to state a claim under $\S 2$ of the Sherman Act. ${ }^{5}$ In doing so, the Court drew incorrect inferences from its decision in Aspen Skiing Co. v. Aspen Highlands Skiing Corp. ${ }^{6}$

The Court also missed a key vertical leveraging issue in Trinko. Verizon leveraged its monopoly of local telecommunications network infrastructure by raising the costs or decreasing the quality of services of rival local telecommunications services providers (such as AT\&T) who leased UNEs from Verizon, placing such rivals at a disadvantage. In this manner, Verizon used actions that raised the costs of rivals to preserve its monopoly in the local telecommunications services market. But Verizon also caused a lower number of leases of UNEs to be leased to retailing rivals, and thus incurred a revenue sacrifice. Therefore, the actions of Verizon create liability under the "sacrifice principle" proposed in the Government's brief in Trinko, whereby a defendant is liable if its conduct "involves a sacrifice of short-term profits or goodwill that makes sense only insofar as it helps the defendant maintain or obtain monopoly power."7

The rest of this article is organized as follows. Part II discusses the recent evolution of telecommunications in the United States, including the breakup of AT\&T in 1981 and the major regulatory reform introduced in the Telecommunications Act of 1996 and its implementation. This part also defines and explains the "vertical price squeeze" and "raising rivals' costs" strategies and shows how these strategies may have been implemented in the 1981-96 period in the absence of the judicially imposed business line restrictions created with the breakup of AT\&T in $1981 .{ }^{8}$ This part also describes the Telecommunications Act of 1996 and its implementation. Part III summarizes the Supreme Court's Trinko decision. Part IV discusses issues and problems arising from the Trinko decision. Part V discusses the vertical leveraging issues in Trinko, including foreclosure through a vertical price squeeze as well as through raising rivals' costs. Part VI discusses the application of the

4. Telecommunications Act, 47 U.S.C. § 252(d) (1) (1996).

5. Trinko, 540 U.S. at 416.

6. 472 U.S. 585 (1985).

7. Brief of Amici Curiae United States and the Federal Trade Commission at 16, Verizon Cornmunications Inc. v. Law Offices of Curtis V. Trinko, 540 U.S. 398 (2004) (No. 02-682).

8. The decision that finalized the antitrust suit of the United States against AT\&T and formalized the 1981 AT\&T breakup was United States v. American Tel. and Tel. Co., 552 F. Supp. 131 (D.C. Cir. 1982) [hereinafter "Modification of Final Judgment" or "MFJ"]. 
"sacrifice principle" in antitrust law. Part VII has concluding remarks.

II.

\section{BACKGROUND ON TELECOMMUNICATIONS MARKETS}

\section{A. The 1981 Breakup of ATE'T}

To understand the context of the Trinko case, we need to examine the markets for telecommunications services in the United States going back to the breakup of AT\&T in 1981. The U.S. Department of Justice (USDOJ or Department of Justice) filed a landmark antitrust suit against AT\&T, United States v. American Telephone and Telegraph Co., ${ }^{9}$ in $1974 .{ }^{10}$ After a long antitrust battle, in 1981 AT\&T agreed to break up into eight companies with very limited competition among them. ${ }^{11}$ Emerging from the 1981 breakup, AT\&T's long distance service company retained the AT\&T name while Ameritech, Bell Atlantic, BellSouth, NYNEX, Pacific Bell, Southwestern Bell ("SBC"), and US West (collectively, the Regional Bell Operating Companies, hereinafter "RBOCs") were created with legally protected monopolies in their respective local telecommunications services markets. ${ }^{12}$ A number of facilities-based competitors that owned their own networks - such as MCI, Sprint, Qwest, Level 3, and Williams - entered the long distance market along with hundreds of long distance resellers. Advances in the laser electronics used in fiber-optic transmission also allowed installed networks to enhance their transmission technology. Significant increases in the number of competitors and in the long

9. 642 F.2d 1285 (D.C. Cir. 1980).

10. The government's allegations, among others, were that (i) AT\&T's relationship with Western Electric was illegal, and (ii) AT\&T monopolized the long distance market. The DOJ sought divestiture of both manufacturing and long distance from local service. For a summary discussion of United States v. ATE'T, see generally Roger G. Noll \& Bruce M. Owen, The Anticompetitive Uses of Regulation: United States v. AT\&T, in The Antitrust Revolution: The Role of Economics (John E. Kwoka \& Lawrence J. White eds., 2d ed. Harper Collins, 1999).

11. See generally MFJ, supra note 8 .

12. In 1984, the seven RBOCs had approximately $89 \%$ of local lines. GTE, a company independent of AT\&T, was a monopolist in most of the remaining lines. AT\&T's market share of local lines had remained almost constant since regulation was established by the middle 1930s. See generally Noll \& Owen, supra note 10; David Gabel \& David F. Weiman, Historical Perspectives on Competition and Interconnection between Local Exchange Carriers (Sept. 1995) (manuscript on file with the NYU Annual Survey of American Law); David Gabel, Competition in a Network Industry: The Telephone Industry, 1894-1910, 54 J. Econ. History 543 (1994). 
distance network capacity resulted in vigorous competition in long distance service, and, in 1995, the Federal Communications Commission declared AT\&T to be a "non-dominant" carrier. ${ }^{13}$ Despite network ownership fragmentation, regulations imposed mandatory interconnection among all carriers of the Public Switched Telecommunications Network (hereinafter "PSTN"), guaranteeing interconnection and interoperability among the carriers.

The 1981 breakup of AT\&T allowed each of the RBOCs to remain a monopolist in its own region of the local telecommunications market. The logic of the breakup was that, given the technology at that time, competition was economically feasible in long distance telecommunications markets but not so in local telecommunications markets. The Department of Justice deemed the local telecommunications network to be too expensive to replicate, considering the revenues that it could create, especially from residential and small business customers. Assuming at the time that local telecommunications was a natural monopoly, the USDOJ allowed the RBOCs to remain monopolists in their own respective regions for local telecommunications. ${ }^{14}$

A key concern arose. Since long distance companies have to pick up from and deliver calls to local telecommunications companies, there was a danger that, if an RBOC was allowed to also provide long distance service, that RBOC could leverage its monopoly power in the local telecommunications market to foreclose its rivals in long distance service. The RBOC would achieve this anti-competitive action through the implementation of either a vertical price squeeze strategy or a raising rivals' costs strategy, as explained below. The consent decree that formalized the AT\&T breakup, the Modification of Final Judgment (hereinafter "MFJ"), protected the long distance services market from these anti-competitive effects by prohibiting the RBOCs from entering the long distance market. ${ }^{15}$

13. In the Matter of Motion of AT\&T Corp. to be Reclassified as a Non-Dominant Carrier, FCC No. 95-427 (October 12, 1995).

14. The author's conclusions regarding the logic of the breakup and the belief that local telecommunications was a natural monopoly at the time are based on private communication of the author with William Baxter, Assistant Attorney General for Antitrust and chief architect of the settlement that resulted in the 1981 breakup of AT\&T. See also Noll \& Owen, supra note 10. RBOCs:

15. The MFJ discusses in detail the line-of-business restrictions imposed on

The second type of restriction imposed upon the Operating Companies is said to be intended to prevent them from engaging in any non-monopoly business so as to eliminate the possibility that they might use their control over exchange services to gain an improper advantage over competitors in such busi- 
In summary, as part of the court decision implementing the 1981 breakup of AT\&T, RBOCs were not allowed to enter the long distance service market. ${ }^{16}$ This prohibition aimed to prevent RBOCs from (i) leveraging their monopoly power in the local market to implement a "vertical price squeeze" of long distance rivals and (ii) raising long distance rivals' costs. ${ }^{17}$ I will first discuss vertical leveraging in the context of the post-AT\&T-breakup market structure and the wisdom of the MFJ in imposing business restrictions on the RBOCs. I will then return to the vertical issues related to the Trinko case.

nesses. Thus, the Operating Companies would not be permitted (1) to manufacture or market telecommunications products and customer premises equipment; (2) to provide interexchange services, (3) to provide directory advertising such as the Yellow Pages; (4) to provide information services; and

(5) to provide any other product or service is not a "natural monopoly service actually regulated by tariff."

MFJ, supra note 8 , at 143 .

16. $I d$.

17. The MFJ notes that in the presence of line of business restrictions there will be no incentive and ability for AT\&T (or the RBOCs) to engage in the anticompetitive conduct alleged:

As indicated in Part IV(A) supra, the ability of AT\&T to engage in anticompetitive concluct stems largely from its control of the local Operating Companies. Absent such control, AT\&T will not have the ability to disadvantage competitors in the interexchange and equipment markets.

For example, with the divestiture of the Operating Companies AT\&T will not be able to discriminate against intercity competitors, either by subsidizing its own intercity services with revenues from the monopoly local exchange services, or by obstructing its competitors' access to the local exchange network. The local Operating Companies will not be providing interexchange services, and they will therefore have no incentive to discriminate. Moreover, AT\&CT's competitors will be guaranteed access that is equal to that provided to AT\&T, and intercity carriers therefore will no longer be presented with the problems that confronted them in that area. See Part VIII, infra.

Id. at 165 .

Moreover, the D.C. Circuit reaffirmed:

First. AT\&T will no longer have the opportunity to provide discriminatory interconnection to competitors. The Operating Companies will own the local exchange facilities. Since these companies will not be providing interexchange services, they will lack AT\&T's incentive to discriminate. Moreover, they will be required to provide all interexchange carriers with exchange access that is "equal in type, quality, and price to that provided to AT\&T and its affiliates." Proposed Decree, Section II. See Part VIII infra.

Id. at $171-72$.

See also the discussion of the logic of the MFJ business restrictions at id., note 13 . 


\section{B. What is a Vertical Price Squeeze and How Does it Lead to the} Foreclosure of Downstream Rivals by an Upstream Monopolist?

I begin by introducing the notion of a vertical price squeeze through an example. Consider a phone call from New York City to Boston under the MFJ restrictions. It is carried by a local telephone company, formally known as a local exchange carrier (here Verizon), within New York City up to the switch of a long distance company (which $\mathrm{I}$ will denote in Figure 1 by $\mathrm{S}_{\mathrm{NYC}}$ ), say of AT\&T. Then the phone call is carried by the long distance company (here AT\&T) to its switch in Boston (denoted by $\mathrm{S}_{\mathrm{BO}}$ ) and handed over to the local exchange carrier (in this case, again Verizon) to be carried to the terminating destination. The path of the phone call from Verizon in NYC to AT\&T to Verizon in Boston is shown in the first line of Figure 1. In terms of pricing, Verizon charges AT\&T an "originating access fee" for transporting the call to AT\&T's NYC switch from the originating party. Verizon also charges AT\&T a "termination access fee" for transporting the call from AT\&T's Boston switch to the terminating party. This is shown in line 2 of Figure 1. In the graphical representation "__ " stands for Verizon while "|IIIIIIII" is for a long distance company, such as AT\&T.

\section{Figure 1: NYC to Boston Phone Call Under the MFJ} Business Line Restrictions

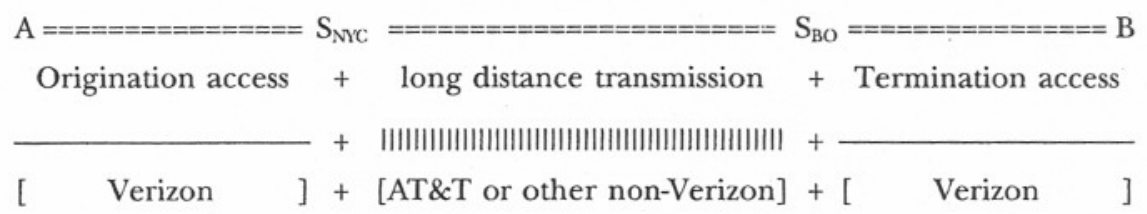

Although to a final consumer the long distance call appears to be and is sold as a single product, it is in fact composed of three components-origination access, long distance transmission, and termination access. Origination access, carrying the call from the consumer's location to the local switch of a long distance company, is provided in New York City by Verizon at price $\mathrm{P}_{\text {O.ACCESS. }}$ Termination access, carrying the call from the long distance switch in Boston to its destination, is provided in Boston by Verizon at price $\mathrm{P}_{\text {T.ACCESS. }}$ Thus, the retail price charged to the customer by AT\&T for the long distance call, $\mathrm{P}_{\mathrm{AB}}$, is the sum of the prices for originating and terminating access that AT\&T pays to Verizon plus the AT\&T price for long distance transmission, $\mathrm{P}_{\mathrm{LD} \text {.TRANSMission, i.e.: }}$

$$
\mathrm{P}_{\mathrm{AB}}=\mathrm{P}_{\text {O.ACCESS }}+\mathrm{P}_{\text {LD.TRANSMISSION }}+\mathrm{P}_{\text {T.ACCESS }}
$$


In a world without the MFJ business line restrictions that preclude the RBOCs from operating in the long distance market, the competitive situation would be dramatically different, as seen in Figure 2. Now, besides the traditional long distance companies, Verizon also carries long distance calls, and Verizon has the advantage of providing origination and termination access to itself as well as to its long distance competitors. The upper part of Figure 2 shows the long distance call carried by AT\&T or any other nonVerizon long distance carrier. The lower part of Figure 2 shows an alternative way to carry the long distance call in the absence of MFJ restrictions: the long distance call is carried all the way, both in its long distance part and its local part, by Verizon.

\section{Figure 2: NYC to Boston Phone Call Without the MFJ Business Line Restrictions}

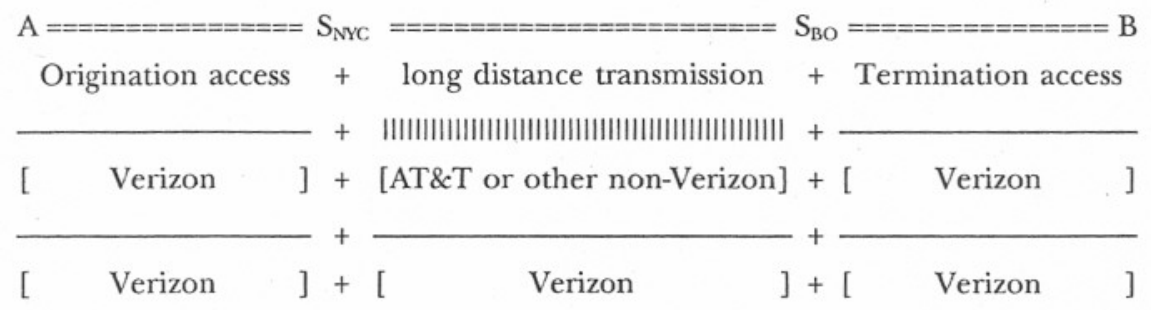

Verizon can now control the end-to-end price of the long distance call $\left(\mathrm{P}_{\mathrm{AB}}\right)$ as well as the prices of originating and terminating access. Thus, a long distance company independent of Verizon would now receive revenue for its long distance transmission from $\mathrm{S}_{\mathrm{NYC}}$ to $\mathrm{S}_{\mathrm{BO}}$ :

$$
\mathrm{P}_{\mathrm{AB}}-\mathrm{P}_{\mathrm{O} . \mathrm{ACCESS}}-\mathrm{P}_{\mathrm{T} . \mathrm{ACCESS}} \text {. }
$$

Notice that now the revenue of a pure long distance company depends on three prices $-\mathrm{P}_{\mathrm{AB}}, \mathrm{P}_{\mathrm{O} \text {.ACCESS }}$, and $\mathrm{P}_{\text {T.ACCESS }}$ - which are all under the control of Verizon and can be manipulated so that the per unit revenue that goes to an independent long distance carrier, 
$\mathrm{P}_{\mathrm{AB}}-\mathrm{P}_{\text {O.ACCESS }}-\mathrm{P}_{\mathrm{T} . \mathrm{ACCESS}}{ }^{18}$ can be "squeezed" to a very small amount. ${ }^{19}$

Foreclosure of competitors can be achieved through a variety of strategies. For example, the upstream monopolist can reduce the price of retail service, $\mathrm{P}_{\mathrm{AB}}$. However, this may be detrimental to its short run profits and therefore under some conditions may be undesirable. Alternatively, the upstream monopolist can increase the price of access origination, $\mathrm{P}_{\text {OACCESS }}$, over which it has a monopoly. Any price $P_{\text {O.ACCESS }}$ above the monopolist's cost will place the long distance rival at a profit disadvantage. ${ }^{20}$ If the final products are undifferentiated, even the smallest deviation of the price of access origination above its cost will result in the foreclosure of an equally efficient long distance rival. That is because the access monopolist charges itself its own costs for access origination while it charges the higher price to long distance rivals.

Thus, the monopolist in the access bottleneck, if allowed to compete in the long distance service market, can leverage its monopoly power in the access bottleneck to foreclose rivals from that market, even when the long distance market would have been competitive absent this foreclosure. ${ }^{21}$ This potential anti-competitive strategy highlights the wisdom of the MFJ business line restrictions prohibiting the RBOCs from providing long distance service.

18. If there is head-on price competition and little or no product differentiation among long distance carriers, Verizon controls price $\mathrm{P}_{\mathrm{AB}}$, which is the same as other carriers can charge for the same service. If there is significant product differentiation, there can be small differences in the prices that Verizon and a pure long distance company can charge, but Verizon can still, through its own pricing, reduce the price $\mathrm{P}_{\mathrm{AB}}$ available to a pure long distance company.

19. Even when the prices for originating and terminating access are regulated and even when they are not under the control of Verizon, still the end-to-end price of long distance is deregulated. Verizon can offer a low enough end-to-end long distance price so that the difference $P_{A B}-P_{O . A C C E S S}-P_{T A C C E S S}$ is squeezed to a very low amount, and thereby independent long distance companies are foreclosed.

20. In fact, access origination and termination have been traditionally set at very high prices compared to cost with the regulatory objective of subsidizing basic service. See generally Nicholas Economides, Telecommunications Regulation: An Introduction (NET Inst., Working Paper \#04-02), available at http://www.stern.nyu.edu/ networks/Telecommunications_Regulation.pdf (on file with the NYU Annual Survey of American Law).

21. The general leveraging argument does not require that Verizon (or any access monopolist) controls both originating and terminating access; for the general argument control of access on either side is sufficient. Since in long distance telecommunications typically the originating party pays, it is generally accepted that the vertical price squeeze will be much more likely when the originating access monopolist also provides long distance service. 


\section{Foreclosure Through Raising Rivals' Costs}

In the previous section we saw how an upstream monopolist could use pricing to foreclose its rivals from a downstream market when the downstream rivals require the use of the monopolized input. I will now show that an upstream monopolist, if allowed in the downstream market, can also foreclose its downstream rivals by raising their costs, by reducing the quality of their product, or by otherwise reducing their profitability through anti-competitive actions. I will show that, in the absence of the MFJ restrictions, even if the regulated monopolist is forced to sell at cost, it will still be able to foreclose its downstream competitors if it can raise its rivals' costs.

Continuing the example of the previous section, suppose now that Verizon is forced by regulators to sell access prices at cost. Then Verizon cannot directly set a price for such services above cost as discussed above. But Verizon can use raising rivals' costs strategies against its long distance competitors, such as delays and quality decreases, so that it increases the effective cost of access, ver-

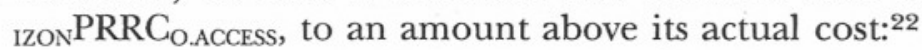

$$
\text { VERIZON } \text { PRRC }_{\text {O.ACCESS }}>\text { VERIZON } C_{\text {O.ACCESS. }}
$$

Let the price of long distance transmission (that is, routing the call from $\mathrm{S}_{\mathrm{NYC}}$ to $\mathrm{S}_{\mathrm{BO}}$ ) to each company be ${ }_{\text {AT\& } \mathrm{T}} \mathrm{P}_{\text {TRANSMISSION }}$ and ${ }_{\text {VER- }}$ IZON $\mathrm{P}_{\text {TRANSMISSION }}$, and assume that the long distance rival is equally efficient with Verizon:

$$
{ }_{\text {AT\& }} \mathrm{P}_{\text {TRANSMISSION }}={ }_{\text {verizon }} \mathrm{P}_{\text {TRANSMISSION. }}
$$

Finally assume that the termination access price $\mathrm{P}_{\text {T.ACCESS }}$ faced by the two companies is the same. ${ }^{23}$ Then, faced with higher effective cost for access origination, equally efficient long distance rivals will have to charge a higher price- ${ }_{\mathrm{AT} \& \mathrm{~T}} \mathrm{P}_{\mathrm{AB}}$-for the final service than Verizon, verizoN $\mathrm{P}_{\mathrm{AB}}$, and will therefore be foreclosed from the long distance market:

$$
\begin{aligned}
& { }_{\text {AT\& } T} \mathrm{P}_{\mathrm{AB}}={ }_{\text {VERIZON }} \mathrm{PRRC}_{\text {O.ACCESS }}+{ }_{\text {AT\& } \mathrm{T}} \mathrm{P}_{\text {TRANSMISSION }}+\mathrm{P}_{\text {T.ACCESS }}= \\
& \text { vERIZON } \text { PRRC }_{\text {O.ACCESS }}+{ }_{\text {vERIZON }} \mathrm{P}_{\text {TRANSMISSION }}+\mathrm{P}_{\text {T.ACCESS }}> \\
& \text { verizON } C_{\text {O.ACCESS }}+\text { verizoN } \mathrm{P}_{\text {TRANSMISSION }}+\mathrm{P}_{\text {T.ACCESS }}=\text { verIZON }_{\text {AB }} \text {. }
\end{aligned}
$$

22. Price when opponent Raises Rivals' Costs (hereinafter "PRRC") represents the effective price of the monopolized input to a downstream rival when the upstream monopolist uses a strategy that raises the costs of rivals or reduces their quality. vERIZONPRRC $\mathrm{C}_{\text {OACCESS }}$ is the effective cost of access origination faced by long distance service rivals as a result of Verizon's raising rivals' costs actions.

23. The argument is strengthened if the RBOC is a monopolist in the termination market as well. 
Therefore, when Verizon implements raising rivals' costs strategies, AT\&T is forced to sell its long distance service above the price at which Verizon sells it:

$$
{ }_{\text {AT\& } \mathrm{T}} \mathrm{P}_{\mathrm{AB}}>{ }_{\text {VERIZON }} \mathrm{P}_{\mathrm{AB}}
$$

Thus, in the absence of the business line restrictions imposed by the MFJ, an RBOC monopolist in access origination could leverage its monopoly and foreclose its long distance rivals either through the use of price strategies, such as setting the price of access above cost, or though strategies that raise the costs of competitors, reduce the quality of their product, or otherwise disadvantage their profitability.

\section{Summary of the Telecommunications Act of 1996}

In the years following the AT\&T breakup, RBOCs mounted a very extensive lobbying effort in Congress to be allowed to provide long distance service, thereby abandoning the restrictions of the MFJ. The resulting law was the Telecommunications Act of 1996, which allowed the RBOCs to offer long distance service under some conditions, which are discussed in detail below, and, at the same time, attempted to open the local telecommunications network to competition. As I discuss below, the Telecommunications Act failed miserably to create competition in local telecommunications. Additionally, as a result of the poor implementation of the Act, existing competition in long distance is likely to diminish. ${ }^{24}$

The Telecommunications Act of 1996 was a landmark reform of the regulatory environment in telecommunications. ${ }^{25}$ Its main objectives included (i) the creation of competition in local telecommunications and (ii) allowing entry of an RBOC in the long distance market once its local market had been opened to competition. Despite this requirement, however, the Telecommunications Act did not have an explicit means of establishing compet-

24. As explained in detail below, RBOCs were allowed to enter the long distance market in their own regions while retaining, in most cases, a near monopoly position in residential and small business local telecommunications markets. As a result, through implementation of a vertical price squeeze and raising rivals' costs strategies by the RBOCs, AT\&T announced in the summer of 2004 that it stopped marketing both local and long distance services to residential customers, and MCI followed a similar strategy, as was revealed in private communication between the author and MCI executives. The two largest companies in long distance, AT\&T and MCI, were significantly weakened, and became takeover targets. At the time of this writing, SBC has just acquired AT\&T, and Verizon is expected to finish the acquisition of MCI in January 2006. See generally Economides, supra note 20.

25. For a deeper discussion of the benefits and costs of telecommunications regulation, see generally Economides, supra note 20. 
itive conditions in local telecommunications markets, such as entrants achieving a significant market share, before the RBOCs could enter the long distance market. ${ }^{26}$ Thus, the Telecommunications Act did not adequately guard against RBOCs leveraging their local telecommunications monopoly power in the long distance market. ${ }^{27}$

In 1996, the "last mile" of the telecommunications network that is closest to the consumer, or the "local loop," remained a bottleneck controlled by incumbent local exchange carriers (hereinafter "ILECs"), RBOCs, GTE, and smaller, typically rural independent telecommunications companies. The Telecommunications Act boldly attempted to introduce competition in this last bottleneck, while also aiming to preserve the effective competition that had developed in the long distance market. ${ }^{28}$

The basic logic behind the Telecommunications Act was to break the network into components and let everyone compete in every part, as well as in end-to-end services. ${ }^{29}$ To achieve this, the Telecommunications Act mandated (i) interconnection; ${ }^{30}$ (ii) unbundling:31 and (iii) non-discrimination. ${ }^{32}$ Moreover, it took away some of the incumbents' advantages that arise purely from historical reasons by (i) mandating that incumbents lease unbundled network elements to entrants at cost-based prices; ${ }^{33}$ (ii) mandating wholesale provision of any service presently provided by the ILECs; ${ }^{34}$ and (iii) imposing number portability. ${ }^{35}$ To preserve competition in long distance, the Telecommunications Act attempted to ensure that monopoly power in the local exchange was not exported to other markets.

Arguing that with the technology available at the time, entry in local telecommunications was uneconomic, Congress defined ways for entrants to share the existing local infrastructure monopolized

26. See generally Telecommunications Act, 47 U.S.C. $\$ \S 251-72$.

27. For an extensive discussion of the Telecommunications Act, see Economides, supra note 20; Nicholas Economides, U.S. Telecommunications Today, in IS Management Handbook (Carol V. Brown \& Heikki Topi eds., Auerbach Publications 2003) available at http://www.stern.nyu.edu/networks/US2002.pdf.

28. See generally Economides, supra note 20; Economides, supra note 27.

29. Economides, supra note 27.

30. Telecommunications Act, 47 U.S.C. $\S \S 251(a),(c)$ (2) (1996).

31. 47 U.S.C. $\S \S 251$ (c) (3), (c) (6),

32. 47 U.S.C. $\S \S 251$ (b) (1), (b) (3), (c) (2) (D), (c) (3), (c) (4) (b), 252(d) (1).

33. 47 U.S.C. $§ 251$ (c) (2).

34. 47 U.S.C. $\$ 251$ (c) (4) (a).

35. 47 U.S.C. $\S 251$ (a) (2). 
by RBOCs and GTE. ${ }^{36}$ Entry in local telecommunications without leasing or sharing the existing network was inherently more difficult than entry in the long distance market. Among the factors that contributed to these difficulties were:

(i) High capital requirements-Building the "local loop" that connected the customer to the network required much more capital per customer than creating a long distance network.

(ii) Location-specific constraints-While many elements/components of the long distance network were moveable, much of the investment in the local exchange has to be made at specific locations. ${ }^{37}$

To facilitate entry in local telecommunications markets, the Act imposed mandatory interconnection among telecommunications networks, unbundled pricing, non-discrimination, and number portability. In particular, Section 251(c)(2) mandated interconnection:

(A) for the transmission and routing of telephone exchange service and exchange access;

(B) at any technically feasible point;

(C) that is at least equal in quality to that provided by the local exchange carrier to itself or to any subsidiary, affiliate, or any other party to which the carrier provides interconnection; and

(D) on rates, terms, and conditions that are just, reasonable, and nondiscriminatory, in accordance with the terms and

36. The Federal Communications Commission put it as follows:

Because an incumbent LEC currently serves virtually all subscribers in its local serving area, an incumbent LEC has little economic incentive to assist new entrants in their efforts to secure a greater share of that market. An incumbent LEC also has the ability to act on its incentive to discourage entry and robust competition by not interconnecting its network with the new entrant's network or by insisting on supracompetitive prices or other unreasonable conditions for terminating calls from the entrant's customers to the incumbent LEC's subscribers.

Congress addressed these problems in the 1996 Act by mandating that the most significant economic impediments to efficient entry into the monopolized local market must be removed. The incumbent LECs have economies of density, connectivity, and scale; traditionally, these have been viewed as creating a natural monopoly. As we pointed out in our NPRM, the local competition provisions of the Act require that these economies be shared with entrants.

Federal Communications Commission, First Report and Order, FCC No. 96-325, at I 10-11 (August 1, 1996).

37. See generally Economides, supra note 20; Economides, supra note 27. 
conditions of the agreement and the requirements of this section and section $252 .{ }^{38}$

Section 251(c) (3) mandated unbundled pricing, that is, offering for sale network elements at "rates, terms, and conditions that are just, reasonable, and nondiscriminatory." 39 To implement interconnection and unbundling, an incumbent was required to allow for physical collocation of equipment at its premises. ${ }^{40}$ Moreover, all companies had the duty to provide number portability, so that consumers could keep their phone numbers if they changed their local service provider. ${ }^{41}$

The Act introduced two novel ways of entry, besides entry through the installation of new facilities. ${ }^{42}$ The first way allowed entry in the retailing part of the telecommunications business by requiring ILECs to sell, at wholesale prices to entrants, any retail service that they offered. Such entry was essentially limited to the retailing part of the market. ${ }^{43}$

The second and most significant novel way of entry introduced by the Act was through the leasing of UNEs from incumbents. In particular, the Act requires that ILECs (i) unbundle their networks; ${ }^{44}$ and (ii) that they offer for lease to entrants network components (unbundled network elements, "UNEs") "at cost plus reasonable profit." ${ }^{45}$ Thus, the Act envisioned the telecommunications network as a decentralized network of interconnected net-

\footnotetext{
38. Telecommunications Act, 47 U.S.C. § 251 (c) (2) (1996).

39. 47 U.S.C. $\S 251$ (c) (3).

40. 47 U.S.C. $\S 251$ (c) (6).

41. 47 U.S.C. $\S 251(\mathrm{~b})(2)$.

42. See Federal Communications Commission, First Report and Order, FCC
} No. 96-325, at II 12 (August 1, 1996).

43. The Act states that prices for resold wholesale services will be set as follows: "a State commission shall determine wholesale rates on the basis of retail rates charged to subscribers for the telecommunications service requested, excluding the portion thereof attributable to any marketing, billing, collection, and other costs that will be avoided by the local exchange carrier." 47 U.S.C. $§ 252$ (d) (3). Notice that, even if all avoided costs are appropriately identified and deducted from final prices, the ILEC is still able to collect the pre-entry retail profit from resold wholesale services.

44. 47 U.S.C. $\$ \S 251$ (c) (3), (c) (6).

45. The FCC and State Regulatory Commissions have interpreted these words to mean Total Element Long Run Incremental Cost which is the forward looking, long run, minimized economic cost of an unbundled element and includes the competitive return on capital. See Federal Communications Commission, First Report and Order, FCC No. 96-325, at § VII (August 1, 1996). 
works. The Federal Communications Commission defined the key UNEs as the "local loop," local switching, and local transport. ${ }^{46}$

Entry through leasing of UNEs would be uneconomical unless prices for the leased elements were set at appropriate prices that imitated competitive prices. The Act ordered that pricing of interconnection or unbundled network elements:

(A) shall be

(i) based on the cost (determined without reference to a rate-of-return or other rate-based proceeding) of providing the interconnection or network element (whichever is applicable), and

(ii) nondiscriminatory, and

(B) may include a reasonable profit. ${ }^{47}$

The appropriate pricing of leased UNEs, transport, and access termination was crucially important for promoting effective competition. The extent to and the speed with which competition would develop depended critically on having prices for UNEs and services that were as close to efficient economic costs as possible. The more prices exceeded efficient economic costs, the less entry there would be. The less entry there was, the less likely it would be that effective competition would develop in local exchange markets, and, if effective competition did develop, it would happen more slowly.

In implementing the Telecommunications Act, the FCC adopted the long-run, forward-looking economic cost as the measure of appropriate costs, or Total Element Long Run Incremental Costs (hereinafter "TELRIC"). ${ }^{48}$ This cost measure fulfilled both the requirement of the Telecommunications Act that the rates for UNEs be nondiscriminatory, and the need for that requirement to apply not only to the rates charged to different entrants, but also between the entrants and the incumbent. ${ }^{49}$

TELRIC is the sum of the costs for all economically efficient inputs required to supply the UNE. ${ }^{50}$ TELRIC has the following features: (1) it is a forward-looking economic cost; (2) it is the lowest cost to provide the service; (3) it is a long-run cost; (4) it is an incremental cost; (5) it includes a competitive return on capital; (6) it excludes monopoly rents; (7) it excludes cross subsidies of any

46. See id. at $\$ 51.319$ (August 1,1996 ).

47. 47 U.S.C. $\S 252$ (d) (1).

48. See Federal Communications Commission, First Report and Order, FCC No. 96-325, at $\S$ VII (August 1, 1996).

49. Id. See also Economides, supra note 20; Economides supra note 27.

50. Federal Communications Commission, First Report and Order, FCC No. 96-325, at § F 51.505 (August 1, 1996). 
kind; and (8) in general, it reflects cost differences among geographic regions. ${ }^{51}$

Using TELRIC as the basis for prices performs several functions, which, in combination, guarantee economic efficiency. First, it gives the right signal to consumers making purchasing decisions among goods, because these decisions are made on the basis of what society must give up to supply these goods. In other words, it achieves allocative efficiency. Second, such a price directs production to the most efficient, lowest-cost suppliers, because these producers can offer the lowest prices. In other words, it achieves productive efficiency. Third, it gives the appropriate signal to firms making decisions of investment, entry, and exit, which are made purely on the basis of forward-looking costs. In other words, it achieves dynamic efficiency. ${ }^{52}$

Prices based on TELRIC plus reasonable profit, as mandated by the Act, for the leasing of UNEs are clearly above the present cost of the local telecommunications network. ${ }^{53}$ The present cost of the local telecommunications network reflects the cost of present-day resources that would be necessary to construct such a network. ${ }^{54}$ Thus, from an economic point of view it is the appropriate cost measure, and it was correctly adopted by the FCC. 55 The incumbent local exchange carriers had argued that the appropriate cost measure would be the historic or "embedded" cost of the network-that is, the cost of the network whenever it was constructed. ${ }^{56}$ However, the historic construction cost of the network does not generally correspond to the cost of the present day resources needed to construct such a network. ${ }^{57}$ There could be many reasons for this phenomenon; I highlight two that show how inappropriate it would be to use historic costs, especially in the case of local telecommunications.

51. Id.

52. See generally Economides, supra note 20; Economides supra note 27.

53. See Federal Communications Commission, First Report and Order, FCC No. 96-325, at § VII (August 1, 1996).

54. See id. at $\S$ F 51.505.

55. Id. The FCC did not calculate the cost of the most efficient current network. Instead it allowed for the locations of switches and central offices of the incumbents to be fixed and calculated the cost of creating a present-day network given these locations. Since these locations could also be optimized in the most efficient network, the cost of the network as calculated by the FCC was higher than that of the most efficient network. Because it kept the old locations of switches and central offices fixed, the network design approved by the FCC was called a "scorched node" network design.

56. See id.

57. Id. 
First, technological change implies very significant cost reductions in the provision of telecommunications services. ${ }^{58}$ For example, a key function in telecommunications is switching and routing calls appropriately. Since the 1950 s, computers have performed this function and technological progress has been immense. To say that the appropriate cost today of a present day PC is billions of dollars because producing a computer with the corresponding computing power would cost that much in 1955 or 1960 is totally absurd. The incumbents' proposal of using historic costs in the face of fast technological change is equally absurd.

Second, telecommunications companies were regulated for a significant period according to "rate of return regulation." Very briefly that meant that a company's profits could not exceed a "capital base" multiplied by a "rate of return," and that the company was therefore guaranteed to recover its network infrastructure investments. ${ }^{59}$ The regulator set the rate of return and the company adjusted its capital base and prices so that its profits would not exceed the capital base times the rate of return. ${ }^{60}$ An expansion of the capital base by a dollar allows the company to increase its allowed profits. Since this regulation guarantees recovery of investment and allows for expansion of profits when the capital base is increased, it is clear that a company has an incentive to keep its capital base high. ${ }^{61}$ Thus, the incumbent local exchange carriers have historically kept their capital base high, and the key element of this capital base is the local network infrastructure. ${ }^{62}$ Therefore, even if historical costs were the appropriate measure of costs (which they are not) the historical costs of the incumbents would have to be adjusted downward significantly because of the distortions caused by the rate of return regulation. ${ }^{63}$

The Telecommunications Act allowed for the entry of RBOCs into the long distance market after they opened their local ex-

58. See generally Economides, supra note 20; Economides, supra note 27.

59. See Harvey Averch \& Leland L. Johnson, Behavior of the Firm Under Regulatory Constraint, 52 Am. Econ. Rev. 1052, 1053-69 (1962); Noll \& Owen, supra note 10 .

60. Averch \& Johnson, supra note 59.

61. See id. at 1053-69 (discussing these and additional distortions created by rate of return regulation).

62. AT\&T long distance repeatedly adjusted its book value downward after competition developed in the long distance market to eliminate the distortion caused by the rate of return regulation. The RBOCs and GTE have not done so.

63. Moreover, it is likely that incumbent local exchange carriers have already recovered the original cost of the vast majority of the physical plant that was in place by 1996 . 
change network to competition. ${ }^{64}$ Thus, from the point of view of an RBOC, long distance entry was supposed to be the reward for allowing competition in the local exchange and forfeiting a local exchange monopoly. The Telecommunications Act was based on the belief that the individual private incentives of the RBOCs would be sufficient to drive the process. Thus, the Telecommunications Act did not impose penalties for delay or non-compliance. This has proved to be a very serious deficiency. ${ }^{65}$ Congress thought that the "carrot" of entry into the long distance market would be a sufficient incentive to compel RBOCs to open their local networks. Events have revealed that Congress erred in this assumption; RBOCs' behavior has shown that they preferred not to open their local network and instead to pay the price of staying out of long distance for a while.

In summary, among other requirements, the Telecommunications Act:

(i) affirmed the mandatory interconnection of telecommunications networks that comprised the Public Switched Telecommunications Network;

(ii) required unbundling of each local telecom network and its pricing;

(iii) imposed the obligation on RBOCs to lease at cost plus reasonable profit the unbundled parts of the local telecommunications network, called UNEs, to any entrant; ${ }^{66}$

(iv) imposed the obligation on RBOCs to provide to entrants at a wholesale discount any service it provides to the public;

(v) imposed other duties on RBOCs, such as non-discrimination, number portability, and co-location of equipment, so that RBOCs would not leverage their monopoly power in the local telecommunications network;

(vi) allowed each RBOC to enter in the long distance service market in its service area (where it used to have a legal monopoly) ${ }^{67}$ once the RBOC unbundled the local network, met non-discriminatory and other requirements, and showed that its entry in long distance was "in the public interest."

64. Telecommunications Act, 47 U.S.C. $\$ 271$ (1996).

65. See generally Economides, supra note 20; Economides supra note 27.

66. In broad categories, the UNEs were (i) the "local loop" the connects the customer premises with the local switch; (ii) local switching services; and (iii) local transport services.

67. The Act also allowed immediate RBOC entry in long distance in locations that were not in its service area. See 47 U.S.C. $\$ \S 271-72$. 


\section{E. Implementation of the Telecommunications Act}

There were very significant delays in the implementation of the Act and a number of legal challenges. There were long delays in the implementation of electronic systems that could easily and at low cost switch large numbers of customer accounts to entrants, as is regularly done for long distance service. There were also significant complaints that incumbent monopolists in the local market were raising the costs of their rivals or lowering their rivals' quality. Allegations included temporarily disconnecting customers who had switched their local telecommunications service provider, and even foreclosing these customers altogether. ${ }^{68}$

By 2004, RBOCs were cleared in all states by the FCC to enter the long distance service market, and this had occurred before local entrants had acquired significant market shares in most areas that would noticeably challenge the monopolistic or dominant position of the incumbent local exchange carriers (RBOCs and GTE in their present, after-mergers combinations) ${ }^{69}$

By 2003 to 2004, local exchange carriers offered bundles of local and long distance services in many areas. In most states, RBOCs were allowed to sell "buckets" of local and long distance minutes, where the customer could use any minute in the bucket either as a local or as a long distance minute. Because the origination and termination access prices significantly exceeded their costs, the introduction of interchangeable buckets of local and long distance minutes created additional disadvantages for companies that participated only in the long distance transmission of calls. The local exchange carrier would charge itself for the cost of originating and terminating access, but it would charge independent long distance companies significantly higher prices for originating and terminat-

68. See, e.g., the California Public Utilities Commission investigation proceedings in MCI Telecomm. Corp. v. Pac. Bell, No. 96-12-026 (Cal. P.U.C. Sept. 24, 1997); Cal. P.U.C. Decision 01-05-087 (May 24, 2001); and Landmark Cases, http:/ /www.blechercollins.com/CM/LandmarkCases/LandmarkCases32.asp (discussing Caltech Int'l Telecom Corp. v. Pac. Bell, No. 97-2105 (N.D. Cal. 2000)). Also, the Trinko case was based on facts that emerged from an earlier investigation of NYNEX's (Verizon's predecessor's) violations of its interconnection agreement with AT\&T by the New York Public Service Commission. NYNEX paid $\$ 10$ million to AT\&T and other competitors for losses arising from violations of its interconnection agreement. See Verizon Communications Inc. v. Law Offices of Curtis V. Trinko, 540 U.S. 398, 402-05 (2004).

69. By 2004, Bell Atlantic, NYNEX and GTE have been combined to form Verizon, SBC has absorbed Ameritech, Pacific Bell, and SNET (Southern New England Telephone), US West has been bought by Quest, and Bell South remains the only RBOC which has not merged since 1981 . 
ing access. Thus, the independent long distance companies would face higher costs and were directly subject to a vertical price squeeze. The main hope for competition remained the possibility that extensive entry into local markets (including the markets for originating and terminating access) would significantly erode the monopoly or dominant position of the incumbent local exchange carriers.

There was a tremendous amount of litigation in the implementation of the 1996 Act. Besides the litigation resulting from implementation in each state, the RBOCs and GTE challenged the FCC rules. The Supreme Court invalidated the first set of FCC rules in ATE'T Corp. v. Iowa Utilities Board. ${ }^{70}$ The Court of Appeals for the D.C. Circuit invalidated much of the second set of FCC rules in United States Telecom Ass'n v. Federal Communications Commission. ${ }^{71}$ The FCC consolidated the remand with its second triennial review of the rules implementing the Act. ${ }^{72}$

Much of the subsequent litigation focused on the issue of "impairment," as described in Section 251(d)(2)(B) of the Act. Section 251 (d) (2) reads:

(2) In determining what network elements should be made available for purposes of subsection (c) (3), the Commission shall consider, at a minimum, whether

(A) access to such network elements as are proprietary in nature is necessary; and

(B) the failure to provide access to such network elements would impair the ability of the telecommunications carrier seeking access to provide the services that it seeks to offer. ${ }^{73}$

After losing the first appeal, the FCC defined impairment as follows: an entrant competitive local exchange carrier (hereinafter "CLEC") would "be impaired when lack of access to an incumbent [local exchange carrier] network element poses a barrier or barriers to entry, including operational and economic barriers, that are likely to make entry into a market uneconomic."74 In the appeal of the second triennial review of the FCC, referred to generally as the USTA II decision, the D.C. Circuit struck down the FCC's findings

70. 525 U.S. 366 (1999).

71. 290 F.3d 415 (D.C. Cir. 2002).

72. See Report and Order and Order on Remand and Further Notice of Proposed Rulemaking, Review of the Section 251 Unbundling Obligations of Incumbent Local Exchange Carriers, FCC No. 03-36 (Feb. 20, 2003) [hereinafter TRO].

73. Telecommunications Act, 47 U.S.C. § 251 (d) (2) (1996).

74. TRO, supra note 72 , at If 84 . 
that entrants would be impaired nationwide with respect to mass market switching. ${ }^{75}$ As a result of this decision and the FCC's subsequent order on remand, ${ }^{76} \mathrm{RBOCs}$ do not have to set up new leases of the "local switching" UNE at prices that reflect cost plus reasonable profit. As an immediate consequence of USTA II, in the summer of 2004, AT\&T, the largest long distance carrier, stopped marketing both local and long distance service to residential customers. SBC acquired AT\&T in November 2005, and Verizon is expected to finish the acquisition of MCI in January 2006. As a result of these acquisitions, there will be a significant reduction in the number and capabilities of independent long distance competitors, resulting in likely price increases in long distance service.

In summary, the Telecommunications Act failed miserably in two of its main objectives. First, it failed to create competition in local telecommunications. Second, the Telecommunications Act was supposed to guard against RBOCs leveraging their monopoly power in local telecommunications service to the long distance market. It completely failed in this too. The failure of the Act was mainly in its implementation. The Act did not impose punishments and penalties for delays in implementation; it harbored the seeds of its own destruction. The Act assumed that the RBOCs, following their own incentives, would allow competition in local telecommunications to flourish so that they would have guaranteed entry into the long distance market. But since there were no specific benchmarks on the degree of necessary competition before an RBOC could enter the long distance market, the RBOCs calculated correctly that they could enter long distance service even when competition in the local service market was minimal, and, in fact, the RBOCs entered long distance in all states without significant competition in local service. Thus, the failure of the Telecommunications Act was to a significant extent the result of insufficient attention to the vertical leveraging that a monopolist or near-monopolist RBOC could exert on entrants that needed to lease parts of the RBOC local telecommunications network to produce and sell local telephone services.

As I will show below, a monopolist RBOC can leverage its monopoly power in the local telecommunications network to foreclose rivals and potential rivals in local telecommunications service who

75. See United States Telecom Ass'n v. Federal Communications Comm'n, 359 F.3d 554, 594-95 (D.C. Cir. 2004).

76. Order on Remand, In the Matter of Unbundled Access to Network Elements, Review of the Section 251 Unbundling Obligations of Incumbent Local Exchange Carriers, FCC No. 04-290 (Dec. 15, 2004). 
need to lease the monopolist's network to compete. This issue of monopoly leveraging was well understood at the time of the breakup of AT\&T in 1981, whereby RBOCs were granted monopolies in local telecommunications markets while competition developed and intensified in long distance. As part of the court decision implementing the breakup of AT\&T, RBOCs were not allowed to enter the long distance service market. As I have explained, this prohibition was created to prevent RBOCs from (i) leveraging their monopoly power in the local market and implementing a "vertical price squeeze" on long distance rivals; and (ii) raising (long distance) rivals' costs.

We will return to the vertical issues related to the Trinko case after summarizing the Supreme Court decision on Trinko.

III.

\section{SUMMARY OF THE SUPREME COURT DECISION IN TRINKO}

The Law Offices of Curtis V. Trinko was a local telecommunications service customer of AT\&T that sued Verizon, alleging that Verizon was implementing an anti-competitive scheme against AT\&T and other local competitors so that Verizon could preserve its monopoly in local telecommunications service. ${ }^{77}$ The allegations included discrimination in fulfilling customer transfer orders to entrants. The district court dismissed all claims and accepted the view of the defendants that a breach of the interconnection agreement between Verizon and AT\&T should be remedied through an administrative process; antitrust litigation would only disrupt the regulatory process of implementation of the Telecommunications Act. ${ }^{78}$ The Second Circuit Court of Appeals reversed the district court's dismissal of Trinko's antitrust claim. ${ }^{79}$ It noted that "it is unlikely that allowing antitrust suits would substantially disrupt the regulatory proceedings mandated by the Telecommunications Act." 80 Moreover, the Second Circuit stated, "while ideally, the regulatory process alone would be enough to bring competition to the local phone service markets, it is possible that the antitrust laws will be

77. Trinko sued NYNEX, which Bell Atlantic eventually absorbed. Bell Atlantic merged with GTE to create Verizon. Verizon Communications Inc. v. Law Offices of Curtis V. Trinko, 540 U.S. 398, 402-05 (2004).

78. Law Offices of Curtis V. Trinko.v. Bell Atl. Corp., 123 F. Supp. 2d 738, 745 (S.D.N.Y. 2000), rev'd, 305 F.3d 89 (2d Cir. 2002), rev'd, 540 U.S. 98 (2004).

79. Law Offices of Curtis V. Trinko v. Bell Atl. Corp., 305 F.3d 89, 113 (2d Cir. 2002), rev'd, 540 U.S. 98 (2004).

80. Id. at 111 . 
needed to supplement the regulatory scheme, especially with respect to injury caused to consumers." ${ }^{81}$ Allowing Trinko's antitrust claim to continue, the Second Circuit held that Verizon's failure to lease parts of its local network to rivals according to the rules of the Telecommunications Act could result in monopolization once all facts are taken into consideration. ${ }^{82}$

The Supreme Court's Trinko decision is organized in four parts. Part I describes the complaint and procedural history of the case. ${ }^{83}$ Part II considers "what effect (if any) the 1996 Act has upon the application of traditional antitrust principles," 84 and concludes that "the 1996 Act preserves claims that satisfy existing antitrust standards [but] does not create new claims that go beyond existing antitrust standards." 85 Part III held that "Verizon's alleged insufficient assistance in the provision of service to rivals is not a recognized antitrust claim under [the Supreme] Court's existing refusalto-deal precedents." 86 Part IV considers whether to extend the Court's existing refusal-to-deal precedents to recognize a $\S 2$ claim for failure to comply with the requirements of the 1996 Act, and concludes that such an extension is unwarranted given the existing regulatory structure designed to enforce the requirements of the 1996 Act. $^{87}$

In particular, the Supreme Court held and reasoned as follows:

(i) Although the Telecommunications Act of 1996 has an antitrust "savings clause," it does not create a different environment than the customary one in the application of antitrust law. 88

(ii) As is well established in antitrust tradition, monopoly by itself is not illegal, and liability requires anti-competitive conduct. ${ }^{89}$

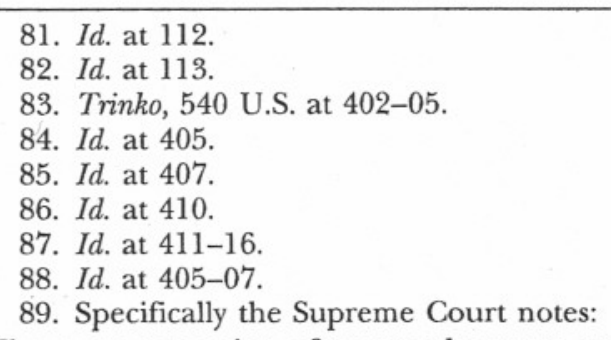

The mere possession of monopoly power, and the concomitant charging of monopoly prices, is not only not unlawful; it is an important element of the free-market system. The opportunity to charge monopoly prices-at least for a short period-is what attracts "business acumen" in the first place; it induces risk taking that produces innovation and economic growth. To safeguard the incentive to innovate, the possession of monopoly power will not be found unlawful unless it is accompanied by an element of anticompetitive conduct. Id. at 407 . 
(iii) Antitrust law only rarely requires cooperation of a monopolist with rivals because:

(a) it can lead to collusion; ${ }^{90}$

(b) may retard innovation; and $\mathrm{d}^{91}$

(c) may reduce investment. ${ }^{92}$

(iv) In Trinko, unlike in Aspen Skiing, the monopolist Verizon did not voluntarily sell the product (here leased UNEs) and then stop selling it or discriminate against rivals. Instead the market for leased UNEs in Trinko was created by regulatory fiat. Aspen Skiing was already "at or near the outer boundary of $\S 2$ liability." 93

(v) The "Essential Facilities" doctrine has no application in Trinko and there is "no need to either recognize [the essential facilities doctrine] or to repudiate it here." 94

(vi) The Court should not get involved in the details of regulatory matters. ${ }^{95}$

\section{IV. \\ ISSUES AND PROBLEMS ARISING FROM THE TRINKO DECISION}

There are several aspects of this decision about which I am troubled as an economist. First, the Court appears concerned that compelling negotiation between competitors could lead to collusion: "Moreover, compelling negotiation between competitors may facilitate the supreme evil of antitrust: collusion." 96 However, in the case of negotiation between an incumbent monopolist local exchange carrier (here Verizon) and an entrant (here AT\&T) there is no possibility of collusion because only the incumbent has the resource (the local exchange network) over which there is negotiation while the entrant(s) has no such network. Thus, there is no

90. "Moreover, compelling negotiation between competitors may facilitate the supreme evil of antitrust: collusion." Id. at 408 .

91 . This is implied by allowing monopoly power and monopoly prices to provide incentives to innovate: "To safeguard the incentive to innovate, the possession of monopoly power will not be found unlawful unless it is accompanied by an element of anticompetitive conduct." Id. at 407.

92. "Judicial oversight under the Sherman Act would seem destined to distort investment and lead to a new layer of interminable litigation, atop the variety of litigation routes already available to and actively pursued by competitive LECs." Id. at 414 .

93. Id. at 409 .

94. Id. at 411.

95. Id. at 411-15.

96. Id. at 408 . 
possibility of negotiation leading to a collusive arrangement among sellers of substitutes. Here the relationship between the incumbent and an entrant is purely a relationship between a buyer and a seller, in which negotiation is standard practice and does not typically raise antitrust concerns. ${ }^{97}$ Moreover, the Telecommunications Act imposes the obligation on the parties to negotiate, ${ }^{98}$ and if the Supreme Court really believed that such negotiations raised antitrust concerns, it should have pointed to other problems, such as the Act's explicit requirement that carriers negotiate. Thus, the Court's concern over compelling negotiation is misguided.

Second, the Court is concerned that the leasing requirement imposed by regulation may reduce investment. ${ }^{99}$ To the extent that antitrust law is useful in increasing the social benefits from the existence and operation of markets, it should be pointed out that increasing social benefits from markets does not necessarily imply that investment should be maximized. In fact, often, markets and trade help reduce investment to the benefit of society. In the case of local telecommunications, it was well understood by Congress in passing the Telecommunications Act of 1996 that the cost of replicating local networks would be prohibitive. The point of the Telecommunications Act was to create competition without duplicating local networks. That is, Congress explicitly and with full consideration of the facts chose a regulatory framework that reduced investment in replication of the incumbent's network facilities and at the

97. The Federal Communications Commission noted:

Congress recognized that, because of the incumbent LEC's incentives and superior bargaining power, its negotiations with new entrants over the terms of such agreements would be quite different from typical commercial negotiations. As distinct from bilateral commercial negotiation, the new entrant comes to the table with little or nothing the incumbent LEC needs or wants.

See Federal Communications Commission, First Report and Order, FCC No. 96325, at Il 15 (August 1, 1996).

98. Section 251(c) of the Telecommunications Act reads:

(c) ADDITIONAL OBLIGATIONS OF INCUMBENT LOCAL EXCHANGE CARRIERS- In addition to the duties contained in subsection (b), each incumbent local exchange carrier has the following duties:

(1) DUTY TO NEGOTIATE- The duty to negotiate in good faith in accordance with section 252 the particular terms and conditions of agreements to fulfill the duties described in paragraphs (1) through (5) of subsection (b) and this subsection. The requesting telecommunications carrier also has the duty to negotiate in good faith the terms and conditions of such agreements.

Telecommunications Act, 47 U.S.C. § 251 (c) (1996).

99. See generally Trinko, 540 U.S 398. 
same time increased competition. ${ }^{100}$ In requiring incumbent local exchange carriers to lease local networks at cost plus reasonable profit, Congress decided that replication of local networks was economically inefficient and chose regulatory rules that would tend to reduce investment in replication of the incumbent's local network facilities. Nevertheless, less investment in replicating incumbent's facilities does not necessarily imply less investment overall in local telecommunications, since the rules apply only to the legacy networks, and not to new investments.

Third, the Court is concerned about the fact that the market for leasing UNEs was created by regulatory fiat and did not exist voluntarily, so sharing of UNEs was "forced sharing." In the Court's thinking this justifies Verizon's abuses because the price was "costbased" and not "market-based." The decision specifically notes: "Verizon's reluctance to interconnect at the cost-based rate of compensation available under $\S 251$ (c) (3) tells us nothing about dreams of monopoly."101 The Court notes the difference between Trinko and Aspen Skiing, where the defendant refused to sell at duopoly prices to a competitor. ${ }^{102}$ But Verizon was already a monopolist in both the network services and retail services markets; Verizon did not need to "dream of monopoly" since it already had a monopoly in both markets. ${ }^{103}$ The crucial issue for Verizon as it related to Trinko, was how the monopolies in both markets would be maintained. I have outlined above how the practices that raised rivals' costs and otherwise disadvantaged rivals helped Verizon maintain its monopoly.

More generally, I am concerned that here the Court erred in understanding how markets are defined and work. A market is defined by demand for a product or service. Refusal to deal should not be deemed anti-competitive only if it is a refusal to sell at prices significantly above cost, such as monopoly or duopoly prices. As long as the refusal to deal occurs at above-average-cost prices (and lease prices for UNEs were guaranteed to be above cost since they were set by regulation at cost plus reasonable profit), the company engaging in such practices should be found liable since it is clear that

100. For example, the rules of the 1996 Act require incumbents to provide unbundled network elements at rates that will "attract new entrants when it would be more efficient to lease than to build or resell." Verizon Communications, Inc. v. Federal Communications Comm'n, 535 U.S. 623 (2002).

101. Trinko, 540 U.S. at 409.

102. Id. at 408-10.

103. See Nicholas Economides, Katja Seim \& V. Brian Viard, Quantifying the Benefits of Entry into Local Phone Service (manuscript on file with the NYU Annual Survey of American Law). 
if it sold the products or services the company would have collected sufficient revenue to cover its costs. Clearly the Court should have judged Verizon's refusal to sell at above-average-cost prices as anticompetitive.

In Aspen Skiing Co. v. Aspen Highlands Skiing Corp., Aspen Skiing controlled three out of four skiing slopes in Aspen, Colorado with the fourth slope controlled by Aspen Highlands. Aspen Skiing previously offered a joint ticket with its competitor, Aspen Highlands, so that a buyer would be able to ski on all four slopes with revenue shared according to use. In 1978-79 Aspen Skiing discontinued the joint ticket and refused to sell its tickets to Aspen Highlands even at full price, in order to prevent Aspen Highlands from bundling them with its own tickets to recreate the joint ticket that had formerly been available. The Supreme Court affirmed that Aspen Skiing's actions were anti-competitive. ${ }^{104}$ The Court noted:

The refusal to accept the Adventure Pack coupons in exchange for daily tickets was apparently motivated entirely by a decision to avoid providing any benefit to Highlands even though accepting the coupons would have entailed no cost to [Aspen Skiing Co.] itself, would have provided it with immediate benefits, and would have satisfied its potential customers. Thus the evidence supports an inference that [Aspen Skiing Co.] was not motivated by efficiency concerns and that it was willing to sacrifice short-run benefits and consumer goodwill in exchange for a perceived long-run impact on its smaller rival. ${ }^{105}$

Comparing the Aspen Skiing facts to those of Trinko, one can expect that a company (i.e., Verizon) would be more likely to refuse to sell at lower but still above cost prices than at higher prices since that company's revenue would be lower at lower prices. That is, from the point of view of the company committing the anti-competitive act, the incentive to refuse to sell to competitors was higher in Trinko than in Aspen (assuming that margins in Trinko are lower) and therefore, everything else being equal, refusal to deal was more likely to occur in Trinko than in Aspen. If the refusal to deal of the duopolist in Aspen Skiing was anti-competitive, the refusal to deal by the monopolist in Trinko should have been even more damning.

104. Aspen Skiing Co. v. Aspen Highlands Skiing Corp., 472 U.S. 585, 593-608 (1985).

105. "The 'Adventure Pack,' which consisted of a 3-day pass at Highlands and three vouchers, each equal to the price of a daily lift ticket at a Ski Co. mountain. The vouchers were guaranteed by funds on deposit in an Aspen bank, and were redeemed by Aspen merchants at full value." Id. at 594. 
Fourth, when the price is set by regulation below the monopoly price, a monopolist has an incentive to discriminate against rivals by: raising rival's costs; ${ }^{106}$ reducing the quality of the input it sells to rivals; or otherwise impeding access to its product. ${ }^{107}$ In the absence of regulation, a monopolist has the opportunity to charge a high price and to discriminate in price against its competitors or potential competitors. In the presence of regulations, such as those imposed by the Telecommunications Act that reduce the price the monopolist could charge below the monopoly price but not below average cost and that require no price discrimination, the monopolist has an incentive to resort to raising rivals' costs strategies so that rivals are disadvantaged. Such strategies increase the cost to rivals and reduce the competition and social welfare that arise from the existence and competitive operation of a market. ${ }^{108}$ Additionally, sometimes raising rivals' costs may impose a cost on the monopolist who is implementing the increases. But the monopolist is willing to bear these costs because of the impact these strategies have in raising prices and foreclosing competition. Although raising rivals' costs strategies are not optimal from the point of view of the monopolist in the presence of unregulated competition, their use can be desirable in the presence of a regulatory environment that prevents the monopolist from setting the monopoly price and restricts price discrimination. ${ }^{109}$ The Court missed this point completely by basing its thinking on Aspen Skiing as an exception, disregarding the fact that there were no regulatory restrictions, and therefore no significant incentives to employ raising rivals' costs strategies. ${ }^{110}$

Fifth, although the reluctance of the Court to get involved in the details of regulatory matters is understandable, that reluctance is misplaced here. For example, the Court could have declared that the degradation of Verizon's service to AT\&T was a monopolistic practice and evaluated its antitrust implications without getting into the details of the regulatory process. As the Second Circuit ob-

106. See generally Steven C. Salop \& David T. Scheffman, Raising Rivals' Cost, 73 Am. Econ. Rev. 267 (1983).

107. See Nicholas Economides, The Incentive for Non-Price Discrimination by an Input Monopolist, 16 INT'L J. Indus. ORG. 271 (1998).

108. See generally Thomas G. Krattenmaker \& Steven C. Salop, Anticompetitive Exclusion: Raising Rivals' Costs to Achieve Power Over Price, 96 YAle L.J. 209 (1986); Economides, supra note 107.

109. See generally Krattenmaker \& Salop, supra note 108; Economides, supra note 107.

110. Verizon Communications Inc. v. Law Offices of Curtis Trinko, 540 U.S. 398, 409 (2004). 
served, there is a way for the antitrust and regulatory setups to work in parallel. ${ }^{111}$

Sixth, there is an important vertical leveraging issue in Trinko that I discuss in the next section.

$$
\begin{gathered}
\text { V. } \\
\text { VERTICAL LEVERAGE IN TRINKO; } \\
\text { RAISING RIVALS' COSTS }
\end{gathered}
$$

\section{A. Foreclosure Through a Vertical Price Squeeze}

Verizon provided and continues to provide two products/services: (i) network infrastructure services (hereinafter "NET services") to itself and to entrants in local telecommunications, such as AT\&T; and (ii) end-user telephone services (hereinafter "retailing services"). At the time of the allegation, Verizon had a monopoly position in both. ${ }^{112}$ The key actions of Verizon in the events leading to Trinko can be seen as the result of Verizon leveraging its monopoly in NET services to preserve its monopoly in retail services. This issue was clearly recognized by the Second Circuit, which noted that Trinko "may have a monopoly leveraging claim," based on the fact that "the defendant '(1) possessed monopoly power in one market; (2) used that power to gain a competitive advantage . . . in another distinct market; and (3) caused injury by such anticompetitive conduct." "113 The Supreme Court dismissed the vertical issue using a fallacious circular argument in footnote four of its decision, stating, "In any event, leveraging presupposes anticompetitive conduct, which in this case could only be the refusal-to-deal claim we have rejected." 114 That is, the Court dismissed the vertical leveraging claim based on the fact that it had dismissed the horizontal claim, as if the vertical claim could not stand on its own. But the vertical leveraging claim did not require a finding of liability on

111. "While ideally, the regulatory process alone would be enough to bring competition to the local phone service markets, it is possible that the antitrust laws will be needed to supplement the regulatory scheme, especially with respect to injury caused to consumers." Law Offices of Curtis V. Trinko v. Bell Atl. Corp., 305 F.3d 89, 112 (2d Cir. 2002), rev'd, 540 U.S. 398 (2004).

112. See Economides, Seim \& Viard, supra note 103. See also Industry Analysis Division, Common Carrier Bureau, Federal Communications Commission, Trends in Telephone Service (March 2000) (indicating in Table 9.4 that the market share of entrants using UNEs in New York State was $0.4 \%$ in $1997,0.4 \%$ in 1998 , and $1.2 \%$ in 1999).

113. Trinko, 305 F.3d at 108 (quoting Virgin Atl. Airways v. British Airways, 257 F.3d 256, 272 (2d Cir. 2001)).

114. Verizon Communications Inc. v. Law Offices of Curtis V. Trinko, 540 U.S. 398,415 n.4 (2004). 
a horizontal refusal-to-deal claim. The leveraging of the network to preserve monopoly can be thought of as a special case of the vertical price squeeze theory, discussed earlier in the context of the 1981 AT\&T breakup, which was well understood by economists, the USDOJ, AT\&T, and the judge implementing the MFJ.

To see this, consider the decomposition of the Verizon services as shown in Figure 3. If Verizon leases UNEs to rivals at a price above cost, it can foreclose any rival for which Verizon's UNEs are required to produce local telecommunications services.

Figure 3: Competition in Local Telecommunications Services

\begin{tabular}{|c|c|c|}
\hline & ET services & Retailing services \\
\hline [ & Verizon & ]$+[\mathrm{AT} \& \mathrm{~T}$ or other non-Verizon] \\
\hline
\end{tabular}

Verizon provides NET services to its own retailing services division at its cost ${ }_{\text {VERIZON }} \mathrm{C}_{\text {NET }}{ }^{115}$ Combined with retailing services, such. as billing and marketing, for which Verizon collects per unit revenue $P_{\text {RETALING }}$, Verizon sells the end-to-end service at price:

$$
\text { verizon } \mathrm{P}_{\text {LOCAL }}={ }_{\text {verizon }} \mathrm{C}_{\text {Net }}+{ }_{\text {verizon }} \mathrm{P}_{\text {RETAILING. }}
$$

If Verizon leases UNEs, or sells NET services, to rivals in the retailing services market at an above-cost price, i.e.:

$$
\text { VERIZON } \mathrm{P}_{\mathrm{NET}}>\text { VERIZON } \mathrm{C}_{\mathrm{NET}} \text {, }
$$

then an equally efficient competitor in retailing, say AT\&T, would be forced out of business because it would have to charge a higher price than Verizon to final customers for local telecommunications service. Assuming equal efficiency in providing retailing services between AT\&T and Verizon, i.e.,

$$
{ }_{\text {AT\& }} \mathrm{P}_{\text {RETAlling }}={ }_{\text {verizon }} \mathrm{P}_{\text {RETAILING, }}
$$

we can see that the price that AT\&T charges for local telecommunications services will be higher than Verizon's:

115. In discussing costs in this section, we assume that all costs calculations are based on the same efficient cost TELRIC methodology. As discussed above, under TELRIC, ILECs are permitted to recover the network costs, certain overhead costs and a reasonable rate of return. Thus, vERIZON $\mathrm{P}_{\text {NET }}>$ vERIZON $\mathrm{C}_{\text {NET }}$ in all circumstances, even if Verizon does nothing additional to raise its rivals' costs (through UNEs or otherwise). 


$$
\begin{aligned}
& \text { AT\& } \mathrm{T} \mathrm{P}_{\text {LOCAL }}={ }_{\text {VERIZON }} \mathrm{P}_{\text {NET }}+{ }_{\text {AT\&:T }} \mathrm{P}_{\text {RETAILING }}= \\
& \text { VERIZON } \mathrm{P}_{\text {NET }}+{ }_{\text {VERIZON }} \mathrm{P}_{\text {RETAILING }}>
\end{aligned}
$$

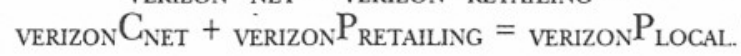

Therefore, if AT\&T leases UNEs (buys NET services) from Verizon above cost, AT\&T is forced to sell local telecommunications services above the price at which Verizon sells them:

$$
\text { AT\& } \mathrm{T} \mathrm{P}_{\text {LOCAL }}>\text { VERIZON } \mathrm{P}_{\text {LOCAL. }}
$$

Thus, AT\&T or any other rival in local telecommunications which has to lease UNEs from Verizon can be foreclosed.

\section{B. Foreclosure Through Raising Rivals' Costs}

Alternatively, now suppose that Verizon is forced by regulators to lease UNEs (sell NET services) at cost. Then Verizon cannot directly set a price for such services above cost, but Verizon can use raising rivals' costs strategies towards its competitors in retailing services, such as delays and quality decreases, so that it increases the effective cost of NET services to them, verIzON PRRC $_{\text {NET }}{ }^{116}$ to an amount above its cost for such services:

$$
\text { VERIZON }_{\text {PRRC }}>_{\text {NERIZON }} C_{\text {NET. }}
$$

Then, using the same argument as in the previous section, faced with higher effective costs for NET services, equally efficient retailing competitors will have to charge a higher price than Verizon's VERIZON $\mathrm{P}_{\text {LOCAL }}$ and will therefore be foreclosed from retailing services. That is, a rival that is equally efficient with Verizon in retailing,

$$
{ }_{\text {AT\& }} \mathrm{P}_{\text {RETAlling }}={ }_{\text {Verizon }} \mathrm{P}_{\text {Retalling, }} \text {, }
$$

will be forced to sell local telecommunications services at a higher price than Verizon:

$$
\begin{aligned}
& { }_{\text {AT\&T }} \mathrm{P}_{\text {LOCAL }}={ }_{\text {VERIZON }} \mathrm{PRRC}_{\mathrm{NET}}+{ }_{\text {AT\&T }} \mathrm{P}_{\text {RETAILING }}= \\
& \text { VERIZON } \mathrm{PRRC}_{\mathrm{NET}}+\text { veRIZON }_{\text {RETAILING }}> \\
& \text { verizon } \mathrm{C}_{\text {NET }}+\text { verizON } \mathrm{P}_{\text {RETAILING }}={ }_{\text {vERIZON }} \mathrm{P}_{\text {LOCAL. }}
\end{aligned}
$$

Therefore, when Verizon implements raising rivals' costs strategies, AT\&T is forced to sell local telecommunications services above the price at which Verizon sells them:

$$
{ }_{\text {AT\&T }} \mathrm{P}_{\text {LOCAL }}>\text { VERIZON } \mathrm{P}_{\text {LOCAL }} \text {. }
$$

116. vERIzONPRRC $\mathrm{NET}_{\mathrm{N}}$ is the effective cost of NET services faced by Verizon local service rivals as a result of Verizon's raising rivals' costs actions. 
Thus, Verizon can use raising rivals' costs strategies to leverage its monopoly in NET services so that it forecloses its competitors in local telecommunications services. Moreover, Verizon has an incentive to do so, since this strategy allows it to maintain its profitable monopoly in local telecommunications services.

\section{VI. \\ APPLICATION OF THE PROFIT "SACRIFICE PRINCIPLE"}

In deciding Trinko, the Supreme Court failed to articulate a clear general rule under which specific conduct will be found to constitute "willful monopolization." The Government's brief in this case proposed such a standard based on the "sacrifice principle."117 In my definition of the sacrifice principle, a defendant is liable for anticompetitive behavior if its conduct "involves a sacrifice of short-term profits or goodwill that makes sense only insofar as it helps the defendant maintain or obtain monopoly power. "118 This definition coincides only partially with the definition of the same principle in the Government's brief. The Government's brief allows all behavior that does not involve sacrifice of short term profits to be characterized as not "exclusionary" and not "predatory." 119 I disagree. Conduct can be

117. Brief of Amici Curiae United States and the Federal Trade Commission at 16, Verizon Communications Inc. v. Law Offices of Curtis V. Trinko, 540 U.S. 398 (2004) (No. 02-682).

118. As the Government brief notes, the sacrifice principle has been used in Aspen Skiing, 472 U.S. at 608, 610-11 (conduct that "sacrifice[s] short-run benefits," such as immediate income and consumer goodwill, undertaken because it "reduc[es] competition . . . over the long run"); General Indus. Corp. v. Hartz Mountain Corp., 810 F.2d 795, 803 (8th Cir. 1987) (conduct anticompetitive if "its 'anticipated benefits were dependent upon its tendency to discipline or eliminate competition and thereby enhance the firm's long term ability to reap the benefits of monopoly power.'"); Stearns Airport Equip. Co. v. FMC Corp., 170 F.3d 518, 523-24 n.3 (5th Cir. 1999) (conduct exclusionary if it harms the monopolist but is justified because it causes rivals more harm); Advanced Health-Care Servs. v. Radford Cmty. Hosp., 910 F.2d 139, 148 (4th Cir. 1990) ("making a short term sacrifice" that "harm[s] consumers and competition" to further "exclusive, anticompetitive objectives"). Brief of Amici Curiae United States and the Federal Trade Commission at 16, Verizon Communications Inc. v. Law Offices of Curtis V. Trinko, 540 U.S. 398 (2004) (No. 02-682).

119. "Conduct is not exclusionary or predatory unless it would make no economic sense for the defendant but for its tendency to eliminate or lessen competition." Brief of Amici Curiae United States and the Federal Trade Commission at 15, Verizon Communications Inc. v. Law Offices of Curtis V. Trinko, 540 U.S. 398 (2004) (No. 02-682). 
exclusionary even without a sacrifice of short term profits. ${ }^{120}$ But when such a sacrifice is observed, it points directly to this conduct as being anti-competitive.

Thus, I am not endorsing the sacrifice principle as a single criterion to be used in ascertaining anti-competitive behavior because there can be cases where there is no short-term profit sacrifice but conduct does not make sense except to attain or retain monopoly power. If an action involves a sacrifice of profits that cannot be justified except to the extent that it helps a company to create, protect, or enhance monopoly power, there is little doubt that such an action is anti-competitive.

I note that vertical leveraging as analyzed above passes the "sacrifice test." In the particular actions alleged in Trinko it is clear that the behavior of Verizon to raise the costs of rivals in local telecommunications services entailed a sacrifice of profits from potential leases of the local telecommunications network to entrants in the retail market, and that this sacrifice would not have occurred if Verizon were not trying to protect its monopoly in the retail market for local telecommunications services. Thus, under the sacrifice principle, Verizon's actions are found to be anti-competitive.

In particular, if Verizon did not have a retailing division and did not try to preserve its monopoly in retailing, it would have no incentive to foreclose or disadvantage independent retailing firms. In fact, if its strategy were not to preserve its monopoly position in retailing, Verizon would have had every incentive to sell its NET services to all, even at prices of cost plus reasonable profit as mandated by the Telecommunications Act. Since Verizon sells its NET services to its retailing division at cost while any NET services price sold to third parties includes a reasonable profit, raising rivals' costs actions that disadvantage third party retailing firms and result in smaller sales of NET services to these firms clearly impose a sacrifice of profits for Verizon. Thus, one could apply the "sacrifice" principle in the Trinko case, in the same way that the Supreme Court articulated it in Aspen Skiing, to conclude that Verizon's raising rivals' costs actions result in a sacrifice of revenue and therefore would not have been taken except to preserve its monopoly.

120. For example, a dominant firm may allow a buyer to buy its product only if it does not buy products from a competitor. Such a contract can be easily characterized as exclusionary even though it may not involve a sacrifice of profits. 
VII.

\section{CONCLUDING REMARKS}

From an economist's point of view, Trinko is a poor decision that will enhance and preserve the monopoly of Verizon and other RBOCs who remain near-monopolists in local telecommunications markets. The Supreme Court focused narrowly on the horizontal issues of the case and missed the leveraging of monopoly power from the network infrastructure market to the retail telecommunications market. Both of these markets were at the time monopolized by Verizon, but the retail telecommunications market faced the possibility of significant competition if Verizon adhered to the terms of the Telecommunications Act of 1996 in leasing network infrastructure to its rivals in the retail market. This paper shows that Verizon had incentives to leverage its monopoly in network infrastructure so as to preserve its monopoly in the retail market. This could be done through various strategies that raised rivals' costs and otherwise disadvantaged competitors. The issue of use of non-price strategies of raising rivals' costs was particularly important because of the price regulation imposed by the Telecommunications Act of 1996. The Supreme Court ignored these issues and decided this case in the context of Aspen Skiing where regulation was absent.

Even in the context of Aspen Skiing, however, the Court erred in its application of precedent. The Supreme Court had affirmed that Aspen Skiing's action of not selling its tickets to a competitor (who wanted to sell them as a bundle with its own) was anti-competitive. Comparing the Aspen Skiing facts to those of Trinko, one can expect that Verizon would be more likely to refuse to sell at lower but still above cost prices than at higher prices since that company's revenue would be lower at lower prices. That is, from the point of view of the company committing the anti-competitive act, the incentive to refuse to sell to competitors is higher in Trinko than in Aspen and therefore, everything else being equal, refusal to deal is more likely to occur in Trinko than in Aspen. If the refusal to deal of the duopolist in Aspen Skiing is anti-competitive, the refusal to deal by the monopolist in Trinko should be even more damning. Thus, the Court failed to apply in Trinko the logic of the argument it had used to deem the actions in Aspen Skiing anti-competitive.

In the particular actions alleged in Trinko, it is clear that the behavior of Verizon to raise the costs of rivals in local telecommunications services entailed a sacrifice of Verizon's profits from network leases that were not signed because Verizon was trying to protect its local telecommunications monopoly. Thus, under the 
sacrifice principle, Verizon's actions were anti-competitive. Overall, the Supreme Court's Trinko decision missed the essence of the anticompetitive behavior involved. 